\title{
Efficacy Assessment of Insecticidal Alternation for the Management of Jassid (Amrasca biguttula biguttula Ishida) and Aphid (Aphis gossypii Glover) Pest of Bt Cotton
}

\author{
Bhavna Verma ${ }^{1 *}$, Ravikant Soni ${ }^{2}$, S.B. Singh ${ }^{3}$ and R.K. Choudhary ${ }^{4}$ \\ ${ }^{1}$ Department of Plant Protection Quarantine and Storage, CIPMC, Indore (MP.), India \\ ${ }^{2}$ Dr. B. R. Ambedkar University of Social Sciences, Mhow, Indore (MP.), India \\ ${ }^{3}$ Department of Horticulture, Mandsour (M.P.), India \\ ${ }^{4}$ Department of Agriculture, Indore (M.P.), India \\ *Corresponding author
}

\section{A B S T R A C T}

\section{Keywords}

Alternation,

Efficacy,

Insecticides, Bt

cotton, Jassid,

Aphid

Article Info

Accepted:

22 October 2019

Available Online:

10 November 2019
The study was conducted during kharif 2014 at College of Agriculture, Indore under All India Coordinated Cotton Improvement Project in Randomized Block Design (RBD) with eight treatments and three replications on Bt cotton hybrid NCS 927, sown on $27^{\text {th }}$ July with $0.6 \times 0.6 \mathrm{~m}$ spacing. All the recommended agronomical practices were adopted. Treatments were planned for alternate use of two insecticides during six sprays. The spraying was done at 10 days interval with 500 litre water per hectare, using knapsack sprayer fitted with a duromist nozzle. These treatments were prepared as $\mathrm{T}_{1}$. Imidacloprid (70\%WG) @ 24.5 gai/ha \& Oxydmeton methyl (25\%EC) @ 250 gai/ha, $\mathrm{T}_{2-}$ Thiaclorprid $(21.7 \% \mathrm{SC}) @ 30$ gai/ha \& Dimethoate $(30 \% \mathrm{EC})$ @ 250 gai/ha, $\mathrm{T}_{3-}$ Imidacloprid $(17.8 \% \mathrm{SL}) @ 25$ gai/ha \& Acephate $(75 \% \mathrm{SP}) @ 250$ gai/ha, T4- Imidacloprid (30.5\%SC) @ 26.25 gai/ha \& Thiamethoxam (25\%WG) @ 37.5 gai/ha, $\mathrm{T}_{5-}$ Spiromesifen (22.9\%SC) @ 144 gai/ha \& Deltamethrin (2.8\%EC) @ 15 gai/ha, $\mathrm{T}_{6}$-Fipronil (5\%SC) @ 100 gai/ha \& Lambdacyhalothrin (4.9\%EC) @ 15 gai/ha, $\mathrm{T}_{7-}$ Acetamiprid (20\%SP) @ 30 gai/ha \& Difenthiuran (50\%WP) @ 300 gai/ha and $\mathrm{T}_{8}$ - Untreated check. All the treatments Exhibited a significant reduction in jassid population over untreated check. Treatment $\mathrm{T}_{6^{-}}$Fipronil (5\%SC) @ 100 gai/ha \& Lambdacyhalothrin (4.9\% EC) @ 15 gai/ha showed least pest population in each spray and expressed no significant difference with $\mathrm{T}_{5^{-}}$Spiromesifen $(22.9 \% \mathrm{SC}) @ 144$ gai/ha \& Deltamethrin (2.8\%EC) @ 15 gai/ha. Similarly the overall jassid population reduction was recorded highest in treatment $\mathrm{T}_{6}(80.56 \%)$ followed by $\mathrm{T}_{5}(74.88 \%)$ and other treatments in which $\mathrm{T}_{1}$ - Imidacloprid (70\%WG) @ 24.5 gai/ha \& Oxydmeton methyl (25\%EC) @ 250 gai/ha (61.21\%) showed least population reduction. Similar trend of efficacy was observed against aphid where treatment $\mathrm{T}_{6}$ showed least pest population in each spray and expressed no significant difference with $\mathrm{T}_{5}$. Again T6 showed highest aphid population reduction (80.56\%) and followed with $\mathrm{T}_{5}(74.88 \%)$. 


\section{Introduction}

Importance of cotton (Gossypium sp.), is well known as it is Kharif cash and fibre crop of India known as the "white gold", cultivated throughout the country. Nimar and Malwa Plateau is basically known for the Bt cotton production in Madhya Pradesh. Among the sucking insect pests, aphid (Aphis gossypii Glover), leafhopper (Amrasca biguttula biguttula Ishida) and other sucking insect pests attack at the early stage of the crop. Higher incidence of aphid and jassid was noted in some $\mathrm{Bt}$ cotton hybrids which exhibited severe losses to Bt cotton crop (N.V.S.S.D. Prasad et al., 2009). The continuous cultivation of $B t$ cotton increased the activities of sucking pests. In present scenario a numbers of sprays of various insecticides are required to manage these insect pests. The continuous and repeated application of various insecticides has created many fold resistance against insecticides (Singh and Jaglan, 2005; Sayyed et al., 2011). To avoid the resistance against insecticides present study was planned to assess the efficacy of insecticides use in alternation in each spray.

Sucking pests viz., aphids (Aphis gossypii Glover), leaf hopper (Amrasca biguttula biguttula Ishida), whiteflies (Bemisia tabaci Gennadius) and thrips, (Thrips tabaci Lindeman) are deleterious to the cotton crop growth and development (Vennila et al., 2000). The estimated loss due to sucking pest's complex was up to 21.20 per cent (Dhawan et al., 1988). Sucking pests viz., aphids (Aphis gossypii Glover), leaf hopper (Amrasca biguttula biguttula Ishida), whiteflies (Bemisia tabaci Gennadius) and thrips (Thrips tabaci Lindeman) are deleterious to the cotton crop growth and development (Vennila et al., 2000). The estimated loss due to sucking pest's complex was up to 21.20 per cent (Dhawan et al., 1988). Sucking pests viz., aphids (Aphis gossypii Glover), leaf hopper (Amrasca biguttula biguttula Ishida), whiteflies (Bemisia tabaci Gennadius) and thrips, (Thrips tabaci Lindeman) are deleterious to the cotton crop growth and development (Vennila et al., 2000). The estimated loss due to sucking pest's complex was up to 21.20 per cent (Dhawan et al., 1988). Sucking pests viz., aphids (Aphis gossypii Glover), leaf hopper (Amrasca biguttula biguttula Ishida), whiteflies (Bemisia tabaci Gennadius) and thrips (Thrips tabaci Lindeman) are deleterious to the cotton crop growth and development (Vennila et al., 2000). The estimated loss due to sucking pest's complex was up to 21.20 per cent (Dhawan et al., 1988).

\section{Materials and Methods}

The investigation was undertaken during kharif 2014 at College of Agriculture, Indore under All India Coordinated Cotton Improvement Project in Randomized Block Design (RBD) with eight treatments including untreated check and three replications. The $\mathrm{Bt}$ cotton hybrid NCS 927 was sown on $27^{\text {th }}$ July with the spacing of $0.6 \times 0.6 \mathrm{~m}$. All the recommended agronomical practices were adopted for the proper growth of the crop. Application of continuous six sprays was planned with two insecticides in each treatment for alternate use at 10 days interval with 500 litre water per hectare, sprayed by knapsack sprayer fitted with a duromist nozzle. These treatments were marked as $\mathrm{T}_{1}$. Imidacloprid (70\%WG) @ 24.5 gai/ha \& Oxydmeton methyl (25\%EC) @ 250 gai/ha, $\mathrm{T}_{2-}$ Thiaclorprid $(21.7 \% \mathrm{SC}) @ 30$ gai/ha \& Dimethoate (30\%EC) @ 250 gai/ha, $\mathrm{T}_{3-}$ Imidacloprid (17.8\%SL) @ 25 gai/ha \& Acephate (75\% SP) @ 250 gai $/$ ha, $\mathrm{T}_{4}$ Imidacloprid (30.5\%SC) @ 26.25 gai/ha \& Thiamethoxam (25\%WG) @ 37.5 gai/ha, $\mathrm{T}_{5-}$ Spiromesifen (22.9\%SC) @ 144 gai/ha \& Deltamethrin (2.8\%EC) @ 15 gai/ha, $\mathrm{T}_{6}$ Fipronil (5\%SC) @ 100 gai/ha \& 
Lambdacyhalothrin (4.9\%EC) @ 15 gai/ha, T7. Acetamiprid (20\%SP) @ 30 gai/ha \& Difenthiuran (50\%WP) @ 300 gai/ha and $\mathrm{T}_{8}$ Untreated check. Observations were recorded at pre spraying and post spraying after 10 days in each spray on five randomly selected tagged plants per plot.

Jassid population were counted on 5 tagged plants per plot with 2 lower, 2 middle and 1 upper leaves per plant and averaged as pest population/5 leaves. Aphid population was counted from $10 \mathrm{~cm}$ long twig/plant and five plants /plot.

The data was averaged and analyzed statistically and presented in table 1. Finally the overall population reduction was calculated based on pretreatment observation and observation of last spray.

\section{Results and Discussion}

\section{Jassid}

Jassid population (Table 1 and Fig. 1) ranged from 32.34 to 34.21 per 5 leaves before spray of insecticides. All the treatments exhibited a significant reduction in insect population over the untreated check. After first spray highest population reduction was noted in each treatment but in the rest of the sprays insect population reduction was slight. Treatment T6- Fipronil (5\%SC) @ 100 gai/ha \& Lambdacyhalothrin (4.9\%EC) @ 15 gai/ha showed least pest population in each spray and expressed no significant difference with T5Spiromesifen (22.9\%SC) @ 144 gai/ha \& Deltamethrin(2.8\%EC) @15 gai/ha.

Only in second spray additionally treatment $\mathrm{T}_{4}$ - Imidacloprid $(30.5 \% \mathrm{SC}) @ 26.25 \mathrm{gai} / \mathrm{ha} \&$ Thiamethoxam (25\%WG) @ 37.5 gai/ha found at par with T6 and T5. Finally based on overall population reduction treatment $\mathrm{T} 6$ showed highest reduction in insect population
$(80.56 \%)$ and followed with T5 (74.88\%), T2Thiaclorprid (21.7\%SC) @ 30 gai/ha \& Dimethoate (30\%EC) @ 250 gai/ha, (69.20\%), T3- Imidacloprid (17.8\%SL) @ 25 gai/ha \& Acephate $(75 \% \mathrm{SP}) @ 250$ gai/ha (67.39\%), T4- Imidacloprid (30.5\%SC) @ 26.25 gai/ha \& Thiamethoxam (25\%WG) @ 37.5 gai/ha $(64.57 \%)$, T7- Acetamiprid (20\%SP) @ 30 gai/ha \& Difenthiuran (50\%WP) @ 300 gai/ha (62.32\%) and T1Imidacloprid (70\%WG) @ 24.5 gai/ha \& Oxydmeton methyl (25\%EC) @ 250 gai/ha $(61.21 \%)$.

Saner et al., (2013) showed that population of jassid, aphid, thrip was promisingly suppressed by fipronil $80 \mathrm{WG}$, followed by fipronil 5 SC, acetamiprid $20 \mathrm{SP}$ and lambdacyhalothrin 5 SC. Bodaa and Ilyash (2017) observed better efficacy of spiromesifen 240 SC and fipronil 45 SC against aphid and jassid in cotton.

Further, Patil et al., (2014) noticed that lambda cyhalothrin 5EC @ 0.004\% was found most effective after thiamethoxam against okra aphid. Indhumathi et al., (2017) revealed that fipronil 200SC @ 40 and 50 g.a.i./ha were highly effective in checking the mean population of aphid, Myzus persicae in chilli.

Kumar et al., (2017) expressed that the three applications of fipronil $5 \mathrm{SC}$ (1 ml /lit) was found significantly most effective after Imidacloprid 17.8 SL (0.5 $\mathrm{ml} /$ lit), which caused maximum population reduction per cent of sucking insect pest of brinjal like aphid, and jassid. Kharel et al., (2016) found the effectiveness of Spiromesifen 240 SC @ $150 \mathrm{~g}$ a.i./ha against jassid (Empoasca kerri) in green gram.

The above findings of these researchers against jassid in cotton and other crops are in close association with the present investigation. 


\section{Aphid}

Aphid population (Table 2 and Fig. 2) ranged from 20.35 to 22.65 per $10 \mathrm{~cm}$ twig. Effectiveness of all the treatments showed significant difference with untreated check. The highest population reduction was noted after first spray in each treatment but in rest of the sprays insect population decreased slightly up to the last spray.
In each spray the least aphid population was recorded in T6- Fipronil (5\%SC) @ 100 gai/ha and Lambdacyhalothrin (4.9\%EC) @ $15 \mathrm{gai} / \mathrm{ha}$ as $14.93,10.81,7.65,5.39,4.74$ and 3.45 per $10 \mathrm{~cm}$ twig, respectively, exhibited highest efficacy. Treatment T5- Spiromesifen $(22.9 \% \mathrm{SC}) @ 144$ gai/ha and Deltamethrin (2.8\%EC) @ 15 gai/ha performed no significant difference with T6 in all the sprays.

Table.1 Efficacy of insecticides against jassid in Bt cotton.

\begin{tabular}{|c|c|c|c|c|c|c|c|c|c|}
\hline \multirow[t]{2}{*}{ Treatments } & \multirow{2}{*}{$\begin{array}{l}\text { Dosage } \\
\text { g.a.i./ha }\end{array}$} & \multirow{2}{*}{$\begin{array}{l}\text { Pre- } \\
\text { treat } \\
\text { ment }\end{array}$} & \multicolumn{6}{|c|}{ Jassid population /5 leaves 10 Days After Sprays } & \multirow{2}{*}{$\begin{array}{c}\text { Overall } \\
\text { Population } \\
\text { reduction }(\%)\end{array}$} \\
\hline & & & $\begin{array}{c}1^{\text {st }} \\
\text { spray }\end{array}$ & $\begin{array}{c}2^{\text {nd }} \\
\text { spray }\end{array}$ & $\begin{array}{c}3^{\text {rd }} \\
\text { spray }\end{array}$ & $\begin{array}{c}4^{\text {th }} \\
\text { spray }\end{array}$ & $\begin{array}{c}5^{\text {th }} \\
\text { spray }\end{array}$ & $\begin{array}{c}6^{\text {th }} \\
\text { spray }\end{array}$ & \\
\hline \multirow[t]{2}{*}{ T1 } & \multirow[t]{2}{*}{$24.5+250$} & 34.16 & 20.74 & 19.21 & 18.34 & 17.11 & 15.21 & 13.25 & 61.21 \\
\hline & & $(5.89)$ & $(4.61)$ & $(4.44)$ & $(4.34)$ & $(4.20)$ & (3.96) & (3.71) & \\
\hline \multirow[t]{2}{*}{ T2 } & \multirow[t]{2}{*}{$30.0+250$} & 32.34 & 18.25 & 17.25 & 14.75 & 13.30 & 11.86 & 9.96 & 69.20 \\
\hline & & $(5.73)$ & $(4.33)$ & $(4.21)$ & $(3.90)$ & $(3.71)$ & $(3.52)$ & $(3.23)$ & \\
\hline \multirow[t]{2}{*}{ T3 } & \multirow[t]{2}{*}{$25.0+250$} & 33.65 & 23.06 & 21.06 & 19.27 & 17.82 & 12.56 & 10.97 & 67.39 \\
\hline & & $(5.84)$ & $(4.85)$ & $(4.64)$ & $(4.45)$ & $(4.28)$ & (3.61) & (3.39) & \\
\hline \multirow[t]{2}{*}{ T4 } & \multirow[t]{2}{*}{$26.25+37.5$} & 33.80 & 18.37 & 16.54 & 15.19 & 13.27 & 12.36 & 11.72 & 64.57 \\
\hline & & $(5.79)$ & $(4.34)$ & (4.13) & (3.96) & $(3.71)$ & (3.59) & $(3.50)$ & \\
\hline \multirow[t]{2}{*}{ T5 } & \multirow[t]{2}{*}{$144.0+15$} & 32.85 & 17.35 & 16.13 & 14.39 & 12.42 & 10.43 & 8.25 & 74.88 \\
\hline & & $(5.77)$ & $(4.22)$ & $(4.08)$ & (3.86) & (3.59) & $(3.31)$ & $(2.95)$ & \\
\hline \multirow[t]{2}{*}{ T6 } & \multirow[t]{2}{*}{$100.0+15$} & 33.45 & 16.31 & 15.78 & 13.44 & 11.45 & 9.91 & 6.50 & 80.56 \\
\hline & & $(5.82)$ & $(4.10)$ & $(4.03)$ & (3.73) & $(3.46)$ & (3.23) & $(2.64)$ & \\
\hline \multirow[t]{2}{*}{ T7 } & \multirow[t]{2}{*}{$30.0+300$} & 34.05 & 21.73 & 19.31 & 17.34 & 16.57 & 13.79 & 12.86 & 62.23 \\
\hline & & (5.87) & (4.71) & $(4.45)$ & $(4.22)$ & (4.13) & (3.78) & $(3.66)$ & \\
\hline \multirow[t]{2}{*}{ T8 } & \multirow[t]{2}{*}{---} & 34.21 & 35.09 & 38.6 & 39.27 & 47.43 & 48.28 & 54.34 & - \\
\hline & & (5.89) & (5.97) & $(6.25)$ & (6.31) & (6.92) & (7.03) & $(7.40)$ & \\
\hline S Em \pm & & - & $(0.07)$ & $(0.06)$ & $(0.05)$ & $(0.08)$ & $(\mathbf{0 . 0 8})$ & $(0.09)$ & \\
\hline CD at $5 \%$ & & NS & $(0.21)$ & (0.17) & (0.16) & $(0.24)$ & $(0.25)$ & $(0.28)$ & \\
\hline CV \% & & - & 5.69 & 4.89 & 3.84 & 6.65 & 7.35 & 8.05 & \\
\hline
\end{tabular}

The values in parentheses are square root transformed values; DAS = Days after spray.

Treatments

$\mathrm{T}_{1-}$ Imidacloprid (70\%WG) @ 24.5 gai/ha and Oxydmeton methyl (25\%EC) @ 250 gai/ha,

$\mathrm{T}_{2}$-Thiaclorprid (21.7\% SC) @ 30 gai/ha and Dimethoate (30\%EC) @ 250 gai $/$ ha,

$\mathrm{T}_{3-}$ Imidacloprid (17.8\%SL) @ $25 \mathrm{gai} / \mathrm{ha}$ and Acephate (75\%SP) @ $250 \mathrm{gai} / \mathrm{ha}$,

$\mathrm{T}_{4}$ - Imidacloprid (30.5\% SC) @ 26.25 gai/ha and Thiamethoxam (25\%WG) @ 37.5 gai/ha,

$\mathrm{T}_{5-}$ Spiromesifen (22.9\%SC) @ 144 gai/ha and Deltamethrin (2.8\%EC) @ 15 gai/ha,

$\mathrm{T}_{6}$-Fipronil (5\% SC) @ 100 gai/ha and Lambdacyhalothrin (4.9\%EC) @ 15 gai/ha,

$\mathrm{T}_{7 .}$ Acetamiprid (20\%SP) @ 30 gai/ha and Difenthiuran (50\%WP) @ 300 gai/ha and

$\mathrm{T}_{8-}$ Untreated check. 
Table.2 Efficacy of insecticides against aphid in $B t$ cotton.

\begin{tabular}{|c|c|c|c|c|c|c|c|c|c|}
\hline \multirow[t]{2}{*}{ Treatments } & \multirow{2}{*}{$\begin{array}{l}\text { Dosage } \\
\text { g.a.i./ha }\end{array}$} & \multirow{2}{*}{$\begin{array}{l}\text { Pre- } \\
\text { treatm } \\
\text { ent }\end{array}$} & \multicolumn{6}{|c|}{ Aphid population/10cm twig 10 Days After Sprays } & \multirow{2}{*}{$\begin{array}{c}\text { Overall } \\
\text { Population } \\
\text { reduction } \\
(\%)\end{array}$} \\
\hline & & & $\underset{\text { spray }}{1^{\text {st }}}$ & $\underset{\text { spray }}{2^{\text {nd }}}$ & $\underset{\text { spray }}{3^{\text {rd }}}$ & $\begin{array}{l}4_{\text {spray }}^{\text {th }} \\
\text { the }\end{array}$ & $\underset{\text { spray }}{5^{\text {th }}}$ & $\underset{\text { spray }}{6^{\text {th }}}$ & \\
\hline \multirow[t]{2}{*}{ T1 } & \multirow[t]{2}{*}{$24.5+250$} & 22.24 & 17.27 & 12.76 & 10.36 & 7.13 & 5.97 & 4.91 & 77.92 \\
\hline & & (4.77) & $(4.22)$ & (3.64) & (3.30) & (2.76) & $(2.54)$ & $(2.33)$ & \\
\hline \multirow[t]{2}{*}{ T2 } & \multirow[t]{2}{*}{$30.0+250$} & 21.65 & 18.15 & 16.74 & 11.72 & 9.64 & 6.23 & 5.83 & 73.07 \\
\hline & & $(4.71)$ & $(4.32)$ & (4.15) & (3.50) & (3.18) & (2.59) & $(2.52)$ & \\
\hline \multirow[t]{2}{*}{ T3 } & \multirow[t]{2}{*}{$25.0+250$} & 20.35 & 17.31 & 12.96 & 11.2 & 8.08 & 5.95 & 4.54 & 77.69 \\
\hline & & $(4.57)$ & (4.22) & (3.67) & (3.42) & (2.93) & (2.53) & $(2.24)$ & \\
\hline \multirow[t]{2}{*}{ T4 } & \multirow{2}{*}{$\begin{array}{c}26.25+37 \\
5\end{array}$} & 20.55 & 18.81 & 13.78 & 9.27 & 6.44 & 5.47 & 4.22 & 79.46 \\
\hline & & $(4.59)$ & (4.39) & (3.78) & (3.13) & (2.63) & (2.44) & $(2.17)$ & \\
\hline \multirow[t]{2}{*}{ T5 } & \multirow[t]{2}{*}{$144.0+15$} & 22.44 & 15.34 & 11.21 & 7.92 & 5.89 & 4.93 & 4.12 & 81.63 \\
\hline & & (4.79) & $(3.98)$ & $(3.42)$ & (2.90) & $(2.53)$ & $(2.33)$ & (2.14) & \\
\hline \multirow[t]{2}{*}{ T6 } & \multirow{2}{*}{$100.0+15$} & 22.15 & 14.93 & 10.81 & 7.65 & 5.39 & 4.74 & 3.45 & 84.42 \\
\hline & & $(4.75)$ & (3.93) & (3.36) & (2.85) & $(2.43)$ & $(2.29)$ & (1.98) & \\
\hline \multirow[t]{2}{*}{ T7 } & \multirow[t]{2}{*}{$30.0+300$} & 21.69 & 15.96 & 11.25 & 8.86 & 6.98 & 5.96 & 4.53 & 79.11 \\
\hline & & $(4.79)$ & (4.06) & (3.43) & (3.06) & $(2.73)$ & $(2.54)$ & $(2.24)$ & \\
\hline \multirow[t]{2}{*}{ T8 } & \multirow[t]{2}{*}{---} & 22.65 & 33.75 & 33.91 & 34.83 & 34.98 & 35.78 & 41.48 & - \\
\hline & & $(4.81)$ & $(5.85)$ & (5.87) & (5.94) & (5.96) & $(6.02)$ & $(6.48)$ & \\
\hline S Em \pm & & - & $(0.04)$ & $(0.07)$ & $(0.07)$ & $(0.09)$ & $(0.07)$ & $(0.08)$ & \\
\hline CD at $5 \%$ & & NS & $(0.13)$ & $(0.22)$ & $(0.20)$ & $(0.29)$ & $(0.22)$ & $(0.24)$ & \\
\hline CV \% & & - & 3.31 & 6.37 & 6.42 & 8.87 & 6.78 & 8.27 & \\
\hline
\end{tabular}

The values in parentheses are square root transformed values.

DAS $=$ Days after spray.

\section{Treatments:}

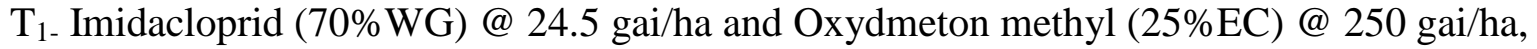

$\mathrm{T}_{2}$ - Thiaclorprid (21.7\% SC) @ 30 gai/ha and Dimethoate (30\%EC) @ 250 gai /ha,

$\mathrm{T}_{3-}$ Imidacloprid (17.8\% SL) @ 25 gai/ha and Acephate (75\%SP) @ 250 gai/ha,

T4- Imidacloprid (30.5\% SC) @ 26.25 gai/ha and Thiamethoxam (25\%WG) @ 37.5 gai/ha,

$\mathrm{T}_{5-}$ Spiromesifen (22.9\%SC) @ 144 gai/ha and Deltamethrin (2.8\%EC) @ 15 gai/ha,

$\mathrm{T}_{6}$-Fipronil (5\%SC) @ 100 gai/ha and Lambdacyhalothrin (4.9\%EC) @ 15 gai/ha,

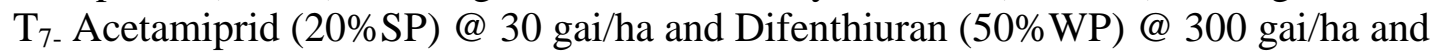

$\mathrm{T}_{8 \text { - Untreated check. }}$ 
Fig.1 Efficacy of insecticides against jassid in $B t$ cotton.

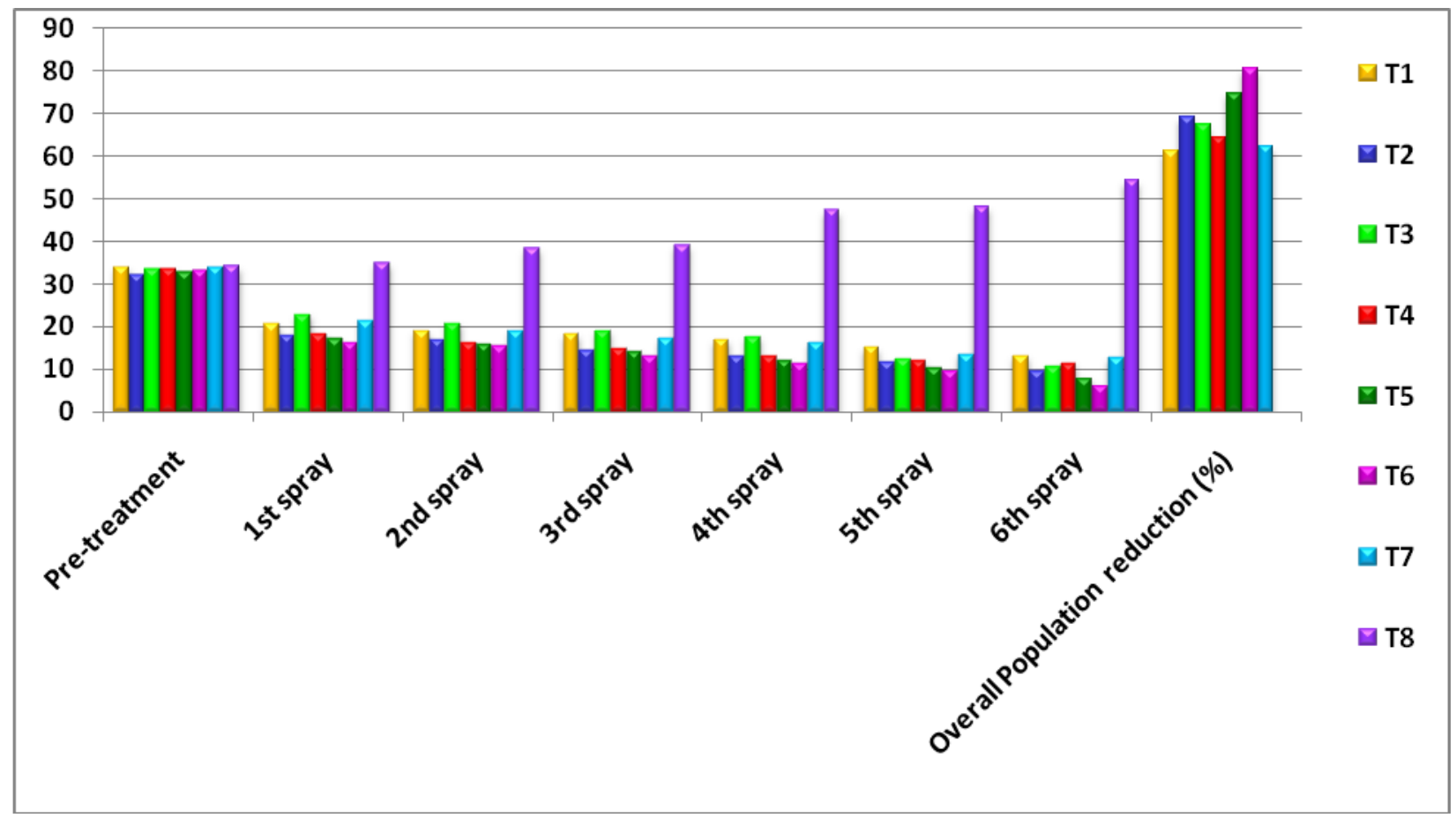

Fig.2 Efficacy of insecticides against jassid in $B t$ cotton

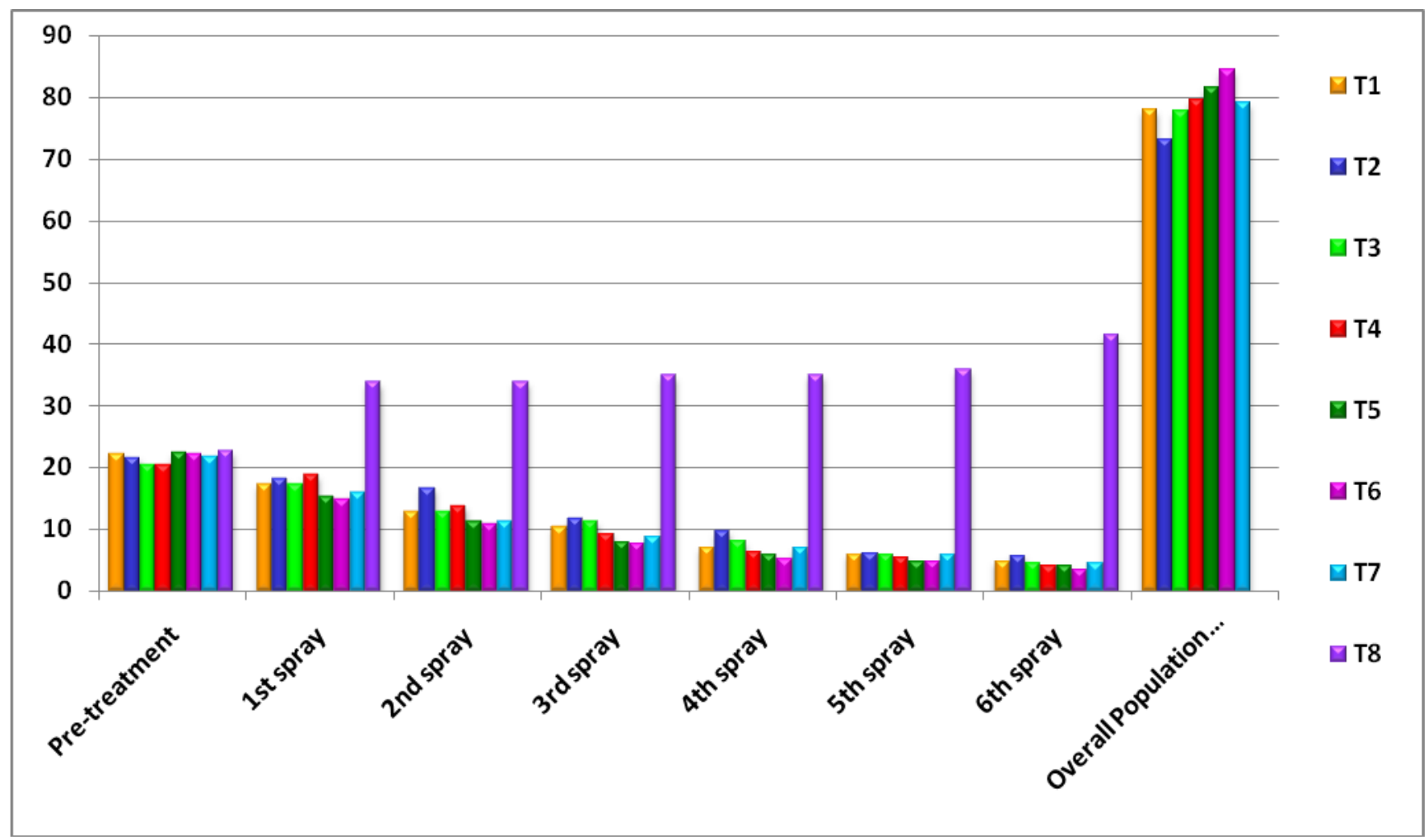

Additionally during fourth, fifth and sixth sprays treatment T4- Imidacloprid (30.5\%SC) 
@ 26.25 gai/ha and Thiamethoxam $(25 \% \mathrm{WG})$ (a) 37.5 gai/ha also found at par with T6 and T5.

The highest overall population reduction was also recorded in T6 $(84.42 \%)$ followed by T5 (81.63\%), T4- Imidacloprid (30.5\%SC) @ 26.25 gai/ha and Thiamethoxam (25\%WG) @ 37.5 gai/ha (79.46\%), T7- Acetamiprid (20\%SP) @ 30 gai/ha and Difenthiuran (50\%WP) @ 300 gai/ha (79.11\%), T1Imidacloprid (70\%WG) @ 24.5 gai/ha and Oxydmeton methyl (25\%EC) @ 250 gai/ha (77.92\%), T 3 - Imidacloprid (17.8\%SL) @ 25 gai/ha and Acephate $(75 \% \mathrm{SP})$ @ 250 gai/ha $(77.69 \%)$ and $\mathrm{T}_{2-}$ Thiaclorprid $(21.7 \% \mathrm{SC}) @$ 30 gai/ha and Dimethoate (30\%EC) @ 250 gai/ha (73.07).

Saner et al., (2013) found the efficacy of fipronil $80 \mathrm{WG}$, followed by fipronil $5 \mathrm{SC}$, acetamiprid $20 \mathrm{SP}$ and lambdacyhalothrin 5 SC against suppressing the population of jassid and aphid,. Kumar et al., (2017) assessed that the three applications of fipronil 5 SC (1 $\mathrm{ml} /$ lit) was found significantly most effective after Imidacloprid $17.8 \mathrm{SL}(0.5 \mathrm{ml} /$ lit $)$ in relation to maximum population reduction of sucking insect pest of brinjal including aphid, and jassid. The results of these researchers are in close conformity and supported the present findings.

\section{Acknowledgements}

The research findings are the part of the research work of PG Programme of the first author to be submitted to the Department of Entomology, Rajmata Vijayaraje Scindia Krishi Vishwa Vidyalaya, College of Agriculture Indore (M.P.) We are very grateful to Dr.R.K. Choudhary and Dr. S. B. Singh to have helped a lot in the research work, field monitoring and data collection.

\section{References}

Bodaa, Vijay and Ilyasb, Mohammad Evaluation of new insecticides against sucking pests of Bt cotton. Int. J. Pl. Animal and Environ. Sci. 2017; 7(2):66-72.

Bhute, N. K., Bhosle, B. B., Bhede, B. V. and More, D. G. Population dynamics of major sucking pests of Bt cotton. Indian J. Entomology. 2012; 74(3): 246-252.

Indhumathi VS, Durairaj C, Gunasekaran K and Nakkeeran S Fipronil200SC-A new formulation for the management of chilli aphid, Myzus persicae. Journal of Entomology and Zoology Studies. 2017; 5(6): 1971-1974.

Kharel, Subin., Singh, P.S. and Singh, S.K. Efficacy of newer insecticides against sucking insect pests of green gram (Vigna radiate (L) Wilczek. International Journal of Agriculture, Environment and Biotechnology. 2016; 9(6): 1081-1087.

Kumar, Rajesh., Mahla, M.K., Singh, Beerendra., Ahir, K.C. and Rathor, N.C. Relative efficacy of newer insecticides against sucking insect pests of brinjal (Solanum melongena), Journal of Entomology and Zoology Studies. 2017; 5(4): 914-917.

Patil, S. R,. Lande, G. K., Awasthi Nikita S. and Barkhsde, U.P. Effect of different doses of insecticides against sucking pests of okra. The Bioscan, 2014; 9(4): 1597-1600.

Prasad, N.V.V.S.D., Rao, Mallikarjuna and Rao, N. Hariprasad Performance of Bt cotton and non Bt cotton hybrids against pest complex under unprotected conditions. Journal of Biopesticides, 2009; 2(1): 107-110.

Saner, D. V., Kabre, G. B., and Shinde, Y. A. Efficacy of newer insecticides on sucking pests in $B t$ cotton under Khandesh region of Maharashtra. International Journal of Plant 
Protection. 2013; 6(2): 405-411.

Sayyed, Muhammad Basit., Saleem A. H. and

Shafqat Saeed M. A. Prot, 2011; 30(6): 705-712.

Singh R. and Jaglan, R. S. Development and management of insecticide resistance in cotton whitefly and leafhopper - a review. Agril. Rev, 2005; 26(3): 229-
234.

Soumya Patil, D Sridevi, T Ramesh Babu and B Pushpavathi Field efficacy of selected insecticides against cowpea aphid, Aphis craccivora (Koch). Journal of Entomology and Zoology Studies. 2017; 5(5): 1603-1607.

\section{How to cite this article:}

Bhavna Verma, Ravikant Soni, S.B. Singh and Choudhary, R.K. 2019. Efficacy Assessment of Insecticidal Alternation for the Management of Jassid (Amrasca biguttula biguttula Ishida) and Aphid (Aphis gossypii Glover) Pest of Bt Cotton. Int.J.Curr.Microbiol.App.Sci. 8(11): 23422349. doi: https://doi.org/10.20546/ijcmas.2019.811.271 